\title{
Antidumping Investigations of the European Union in the Time of Pandemic COVID-19
}

DOI 10.18267/pr.2021.krn.4816.7

\author{
Henrich Juhás ${ }^{1}$ - Zuzana Kittová2 \\ ORCID iD: 0000-0001-8910-0371신 0000-0002-8903-4033² \\ henrich.juhas@euba.sk, zuzana.kittova@euba.sk \\ 1, 2 University of Economics in Bratislava, Faculty of Commerce, International Trade \\ Department \\ Bratislava, Slovakia
}

\begin{abstract}
Antidumping policy of the EU aims at protecting EU producers against unfair practices of foreign companies supplying the EU market. The economic recession could stimulate either the utilization of unfair practices by the foreign businesses, or also the effort of domestic companies to obtain the protection against the foreign competition. As a result, there may be an increase in the number of antidumping investigations. The aim of this paper is to find out how the COVID-19 pandemic and the following economic recession has affected the antidumping investigations in the EU. We found that the number of antidumping initiations has not significantly increased in 2020 compared to previous years. However, pandemic COVID-19 may have negative impact on antidumping investigations duration due to restrictions concerning spot verifications as well as time-limits prolongations. This may limit the ability of the EU to respond quickly to unfair practices by foreign suppliers.
\end{abstract}

Keywords: antidumping measures, investigation, pandemics, European Union

JEL Classification codes: F13, F31, F44

\section{INTRODUCTION}

As the global trade is changing and more subjects step into the spheres of international business, each of them are trying to fix their positions and financial statuses. However, some of them are using the illegal forms of strengthening their sales. To be concrete, besides the subsidies, side "supports" from their governments they often also choose the dumping way of doing business. It is the method when the product is exported from some country at a price lower than the price that is normally charged on the domestic market. As a way to decline the negative impacts of the import of dumped products, the antidumping measures are initiated. However, this type of measures is allowed to use only if there is significant damage to the industry in the region where dumped products are being imported. The rate of damage must be found out by the detailed investigation according to specific rules (Szatmári, 2020). The European Commission, as the responsible body for the Trade policy of European Union, heads these investigations against unfair dumping practices of foreign businesses supplying the EU market. However, as the COVID-19 pandemics influences all spheres of the lives, the international trade is also affected by its negative impacts, mainly by the economic recession. It could strengthen the pressure on the economic subjects which suffer from the negative recessive economic impacts to use the unfair dumping practices. According to this fact, the recession can also support the domestic businesses to obtain the effective protection against the illegal trade operations. During the recession, there is a possibility that both numbers of illegal dumping activities and antidumping investigation initiations would increase. 
Concerning the structure, firstly, the paper maps existing literature in the field of the antidumping investigations affected by the economic recession. Thereinafter, we observe the development of GDP affected by the COVID-19 pandemics and the number of the antidumping investigations initiated in particular period, and this number is compared with the data available for the period before the pandemics. Consequently, the conclusion is implicated, whether COVID-19 pandemics had an impact on the antidumping investigations.

\section{LITERATURE REVIEW}

The antidumping investigations of the European Union may be done under the WTO and GATT conditions. According to Jallab (2007), the antidumping measures consist of three stages: the admissibility of the claim is examined; the dumping margin is estimated, and the size and nature of the damage is assessed. While considering the period of dumping existence investigation, the 1994 GATT agreement states that the period is normally one year, but should not be less than six months. On the other hand, the investigations meant for assessing the damages should cover the 3 years, but they can cover a shorter period. In his research, Jallab dealt with the hypothesis applied for both United States and the European Union that there is a possibility of decrease of the number of inquiries opened with an increase in the rate of growth of the import country's real GDP. He worked also with the potential fact that the sensitivity of the firms to perceived foreign unfair trading activities is increased in an economic recession as is the motivation of foreign firms to decrease prices in order to maintain potential export volumes. Simultaneously, importing country seems it easier to prove an economic injury during the economic recession. In his research, he evaluates the influence of the business cycle with variations in real GDP or the index of the industrial production. The average growth rate of GDP as well as of the industrial production index is used, either over the previous year or over a three-year period before the date of submission. The data for his work were drawn from the WTO Trade Policies Review Division and, at the same time, the data on initiations of antidumping actions in observed period (1990-2002) came from the WTO antidumping database. Based on this research, the economic situations influenced by the recession bring the potential to strengthen the demand for protection, thus contributing to increase of the protectionist tendencies. On the other hand, the periods of economic "boom" are likely to further liberalization of trade. When talking about the causality relationship, it can be expected that submissions are negatively related to the business cycle status - the deeper recession occurred, the more antidumping procedures initiated. However, the results, according to Jallab's research say that "short variations in the level of general economic activity or in the level of industrial activity...have no significant impact on the number of openings of antidumping procedures."

Knetter \& Prusa, 2003 dealt with the relationship between macroeconomic factors and antidumping submissions. This empirical work uses data on antidumping submissions from Australia, Canada, the European Union, and the United States. The starting point of the study are two criteria that must be met in order to impose duties on foreign companies using illegal dumping prices. There must be evidence that domestic industry has suffered relevant material injury as a result of foreign imports. On the other hand, the foreign firms must be found to be pricing at less than fair value which means that the price charged in the domestic market by the foreign firm is below the price charged for the same type of product on other markets. Moreover, the price charged in the domestic market is below the level of estimated costs plus normal returns. The determination of each of these criteria could be affected by the macroeconomic factors in general and fluctuations in real exchange rates. The response of a particular foreign firm to a real exchange rate changes increases the possibility that at least one of the criteria, that were already mentioned, will be satisfied. The research deals with the fact that fluctuation in economic activity might affect the decisions for submissions. According 
to Knetter \& Prusa, it is clear that the economic recession in the importing country causes poor performance of domestic firms. All in all, this could facilitate a finding of material injury. Moreover, there is a possibility for foreign firms to reduce prices on particular shipments to the country of destination, especially below fair value. They worked with the hypothesis that GDP of import country will be related to the submissions negatively. Oppositely, they do not see clear relationship between export country GDP and the submissions. There is a possibility of lowering the prices by the foreign firms if there is a weak foreign economy to maintain overall levels of output. This situation could cause injury to domestic firms, but it is not clear that it would launch the pricing below the fair value. The reason is that foreign companies would presumably be lowering prices to all markets, not only to only one or some particular. One of the main findings of this study is that domestic real GDP growth has statistically significant impact on submissions. One-standard deviation fall in domestic real GDP increases submissions by $23 \%$ according to this study.

The issues concerning the relation between the $A D$ criteria and exchange rates were examined also by Robert Feinberg (1989). The research of the changing country pattern of dumping complaints by the businesses based in USA during the period observed (1982-1987) suggested that the exchange rate fluctuations are marginal factor in determining the case submission. According to him, the prevalence of "unfair trade" is not exogenous with respect to broader macroeconomic considerations. In his later research Feinberg (2003) found that growth in GDP has negative impact on the number of submissions. In his research he used a negative binomial model in order to estimate particular determinants of antidumping submissions in the US in the observed period (1981-1998) quarterly. The results of his research show that US antidumping submissions rose with the appreciation of the US dollar.

Bown \& Crowley (2013) have used the quarterly data for the 5 chosen countries countries USA, EU, Australia, Canada and South Corea with the aim to estimate the impact of macroeconomic fluctuation on the trade protection policies over the year 1988. Using an empirical model, they have found the evidence of a strong countercyclical trade policy response in the pre-Great Recession period. In this time, increases in domestic unemployment rates, real appreciations in bilateral exchange rates and declines in the GDP growth rates of bilateral partners caused the substantial increase in new temporary trade barriers. According to these facts, the results of their research could be presented in a way, that a countercyclical relationship between domestic macroeconomic shocks (domestic unemployment rates increase or domestic real GDP growth reduction) and governments initiating new temporary trade barrier investigations over significantly more imported products per particular trading partner per quarter is apparent.

Barattieri et al. (2021) study the macroeconomic effect on protectionism using the highfrequency trade policy data in their paper. However, even the research deals with the relationship between trade barriers, to be concrete antidumping duties, global safeguards and countervailing duties, and real GDP increase, the direction of the connection is opposite than in our research, as we are investigating the effect of GDP increase on the number of $A D$ investigations. By using the vector autoregressions, they investigate the short-run effects of trade policy on the macroeconomic outcomes. They construct monthly and quarterly measures of temporary trade barriers for chosen country, Canada. According to their research, the trade barriers, which have been already mentioned, were used as the primary policy tool to implement the trade restrictions during the last 20 years. They focused on the $A D$ investigations as the vast majority of trade barriers which leaded to the imposition of AD tariffs and used the data on inflation, GDP, industrial production, trade balance or the real exchange rate to identify the effects of trade policy shocks by exploiting institutional features of $A D$ regulation. There are three conclusions emerge from the empirical research: protectionism is recessionary, inflationary, and has a small positive effect on the trade balance or GDP ratio. 
The other authors, such as Curran (2015) or Park (2009) dealt with the issue of AD investigations of the EU illustrated in particular case, namely the case of the impact of $A D$ investigations on the global production networks of the solar panels, resp. the effect of $A D$ actions on the trade with China. Felbermayr \& Sandkamp (2021) also illustrated the issue of AD investigation on the case of firm-level evidence from China. Moreover, Sandkamp (2020) also dealt with the AD investigations and duties, but also from the side of trade effects. This implies that majority of studies concern AD investigations or measures, but only in general or they deal with the specific case. According to this, some knowledge gap occurred in the field of study examined in our paper. Concerning the fact, that so far no study has examined whether and what impact the recession due to the pandemics has on anti-dumping investigations or may have in the future.

\section{METHODOLOGY}

The aim of the paper is to find out how the COVID-19 pandemic and the following economic recession has affected the antidumping (AD) investigations in the EU. The authors wanted to prove if the economic recession either increased the number of $A D$ investigations in the $E U$ or the impact of this stage of business cycle on the investigations was not particularly significant. According to this reason, an effective methodology that helped to express the causal relationship between the decline in GDP and the number of AD investigations and expiry review investigations initiated by the EU had to be adopted. The article draws on qualitative methods involving secondary data and information analysis. All data was gained from published sources, mainly the foreign articles, as well as from the internet databases.

Firstly, the authors analyzed the whole process of EU AD investigations following the official EU documents and proceedings. While observing the development of investigations according to their stages, the statistical data from the database of European Commission was presented in the table, while the graphic illustrations helped the better illustration of the issue. We analyzed the commodity structure of trade operations belonging to the group of potentially dumped ones, pointing out the most dangerous commodities which were tried to import to the EU. The base for the observation of the relationship between the GDP decrease and AD investigations was "Quarterly GDP indicator" of five countries that were included in the AD investigations process the most. This data was processed graphically where the comparison of GDP changes of particular countries was illustrated. Finally, the issue of influence of COVID19 pandemics on the spot verifications and $A D$ investigations duration too was proceed following the official documents of the EU, namely the EU Regulations. The synthesis of this information provides the overview of the relationship between economic situation and dumping trade operations that could bring the possibility for domestic subjects to request the protection against the foreign competition. Other methods, such as induction and deduction were also used.

\section{RESULTS AND DISCUSSION}

While participating in international trade, some foreign subjects have dumping behaviour, when they are trying to push the domestic manufacturers or small firms out of the market by reducing prices in short term while the level of the reduced prices is often based under their production costs. In this case, the intervention of the particular body, in the case of EU it is the European Commission, is needed. In this matter, the EU should prevent the market from dumping behaviour of foreign companies or international business chains (Baláž, P. et al., 2019). 
This is done by antidumping investigation of the EU. This type of investigation is the process of determination whether the goods being imported into the EU area are being sold at the level that is below the price in the country of production, or this level is under the costs of production. If the industry from the country within the EU send a valid complaint including sufficient evidence of the injury that is caused by the business activity of foreign company, it is obligatory for European Commission (EC) to launch an antidumping investigation. According to the official EC document, "the investigation examines whether:

- dumping is taking place from the country/countries concerned;

- material injury has been suffered by the EU industry;

- it is the dumping that is causing the injury;

- it would be against the economic interests of the EU to impose measures (which are usually in the form of an anti-dumping duty)" (European Commission, 2014).

The investigation must start after 45 days from receiving the official submission from potentially injured subject. After tie initiation, the questionnaires are sent to the exporters in the countries concerned, EU producers and also to the importers and users in the EU who have the deadline for replies to the questionnaires, at least 30 days. If the subject does not reply or do not cooperate in other ways, it will be regarded as not cooperating within the investigation (European Commission, 2014). After at the most 13 months, the publication of definitive measures must be done. During the mentioned 13-month period, provisional duties or other provisional measures could be imposed and other side findings and comments are made. All in all, the usual procedure is to investigate whether or not dumping is taking place over a 6 to 13-month period, including also the process of spot verifications.

However, as researched, restrictions due to the COVID-19 pandemics influences the mentioned spot verifications and the whole $A D$ investigations duration too. According to the Article 16 of Regulation (EU) 2016/1036 of the European Parliament and of the Council of 8 June 2016 on protection against dumped imports from countries not members of the European Union, there is a possibility to carry out the visits to the particular countries where it is appropriate to examine the records of economic subjects (importers, exporters, traders, producers, agents etc.) and to verify all information provided before. However, taking into account the risk arising from pandemics, the Commission decided to suspend all non-essential travel to the areas with high level of infection thus preventing all subjects against the potential threats resulting from face-to-face meetings. Moreover, if the information provided by exporting subject located in the areas with high level of infection is not subject to verification on spot due to the safety measures or travel restrictions, the Commission "will endeavour to consider the information properly submitted by the parties and to cross-check such information with other information available if feasible." If the accuracy of information submitted is not satisfactory or complete, "the Commission have to base its findings only on the verified or other proven facts on the record of the investigation." Due to these matters, strictly cooperation is needed between all interested subjects simultaneously with the need of providing sufficiently detailed and properly certified information that can be crosschecked from independent sources. If such information cannot be provided, the Commission could make its findings and solutions based on the facts available in accordance with Articles 18 and 28 of the respective basic Regulations (European Commission, 2020).

The ability of foreign economic subjects located in areas affected by pandemics to conduct business activities could be limited by the safety measures. It brings the impact on the ability of particular bodies to reply on time to important questionnaires or other requests for information needed in the process of $A D$ investigation. The specific time limit for replying to questionnaires are listed in Articles 6(2) and 11(2) of the respective basic Regulations, while sections $5-9$ of Notices of Initiation could set out additional provisions for the information 
submission and could affect the timeline of investigation. Section 9 of Notices of Initiation states that there is a possibility to grant a 7-day extension in case of exceptional circumstances that can include also COVID-19 pandemics. It is because it could affect economic subjects from complying with the relevant deadlines for information submission as it could occur as an unforeseen event constituting "force majeure". Concerning this fact, the subjects requested for statement must explain how the COVID-19 measures affected their ability to provide all information needed. If there are business subjects located in regions particularly affected by COVID-19 pandemics, they may be subject to other substantial safety and health measures (quarantine, compulsory closures etc.). These measures limit the ability of subjects to comply with the requests of the Commission. In these cases, it may be decided to extraordinarily delay the time limit by other 7 days. The proof of the occurrence of such situation must be clearly provided and according to that, the Commission will assess the cases individually and decide about the extension period of other 7 days. According to the official announcement, "...if these longer extensions for force majeure or additional safety measures would risk jeopardising the timely conclusion of the investigation, the Commission may reject the extension requests or shorten the time granted." (European Commission, 2020).

Considering the facts above, both spot verifications and $A D$ investigations duration can be affected negatively by the COVID-19 pandemics and by the resulting economic and health measures or restrictions.

The whole process of antidumping investigation could be divided into the main stages involving all the activities mentioned above. These stages of the procedure are illustrated by the Figure below.

Fig. 1 The stages of EU AD investigations

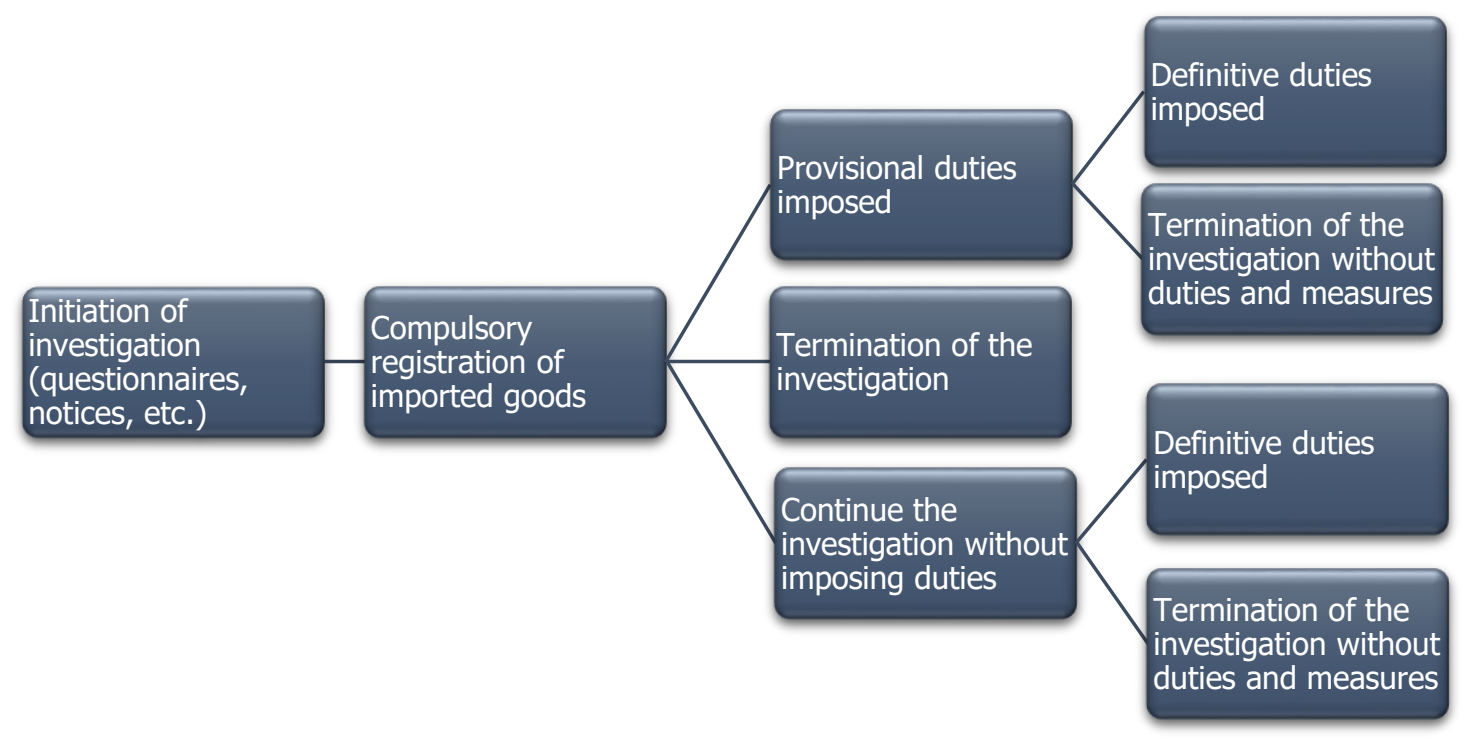

Source: Authors' own processing based on European Commission, 2014

As the Figure 1 shows, the AD investigations of the EU have specific sequences or stages. If there is no doubt about the legal import operations made by foreign subject, the investigation is terminated after the first stage. However, there could be two more situations - the provisional duties could be imposed on the one side, while on the other one the investigation could continue without imposing any duties or measures. Both of these stages could be terminated by one of the potential solutions - imposing or non-imposing the definitive duties or other measures. It is important to add that following the EU publication concerning the 
impending expiry of the anti-dumping measures in force on import of particular goods, the country can request for the review of anti-dumping measures before their expiration (pursuant to Article 11 (2) of Regulation (EU) $2016 / 1036$ on protection against dumped imports from countries not members of the European Union). After the expiry review, the European Commission can impose new anti-dumping duty. Concerning this study, the EU AD investigations are divided according to their stages and are listed below, in Table 1.

Tab. 1 Number of the EU AD investigations according to their stages in the observed period (2015-2020)

\begin{tabular}{|l|c|c|c|c|c|c|}
\hline Stage of investigation / Year & $\mathbf{2 0 1 5}$ & $\mathbf{2 0 1 6}$ & $\mathbf{2 0 1 7}$ & $\mathbf{2 0 1 8}$ & $\mathbf{2 0 1 9}$ & $\mathbf{2 0 2 0}$ \\
\hline $\begin{array}{l}\text { Standard AD investigation } \\
\text { initiations started }\end{array}$ & 7 & 9 & 5 & 4 & 7 & 10 \\
\hline $\begin{array}{l}\text { Investigation proceedings } \\
\text { terminated }\end{array}$ & N/A & 1 & N/A & 1 & 1 & 2 \\
\hline $\begin{array}{l}\text { Compulsory registered import of } \\
\text { goods }\end{array}$ & 1 & 1 & 2 & 2 & 3 & 3 \\
\hline Provisional AD duty imposed & 5 & 6 & 2 & 1 & 2 & 3 \\
\hline Definitive AD duty imposed & 5 & 9 & 10 & 3 & 2 & 7 \\
\hline $\begin{array}{l}\text { Expiry review investigation } \\
\text { initiations started }\end{array}$ & 13 & 13 & 15 & 17 & 6 & 11 \\
\hline $\begin{array}{l}\text { Definitive AD duty imposed } \\
\text { according to expiry review }\end{array}$ & 12 & 10 & 17 & 7 & 11 & 6 \\
\hline
\end{tabular}

Source: authors' own processing based on European Commission Notices database

Table 1 shows the number of the EU antidumping investigations concerning their stages during the observed period of 6 years. According to the solutions we can consider that the development of all stages of EU investigations shows steady or balanced results, except the data collected for the year 2018. There is a significant decrease of number of definitive antidumping duty imposed in this year, which continued till 2019. In 2020, this indicator observed increase again. It is important to present the number of special investigations status - "Expiry review". The table illustrates the paradox, that the number of this type of initiated investigations was on its highest level during the year 2018, when most of the other indicators decreased. The strongest was the year 2016, when the number of imposed definitive AD duty and also the number of definitive AD duty imposed according to the results of expiry review were on their highest levels. Table 1 will form the basis for the following Figure 2 concerning the initiations that started during the observed period. 
Fig. 2 Development of AD initiations in the period of 2015-2020

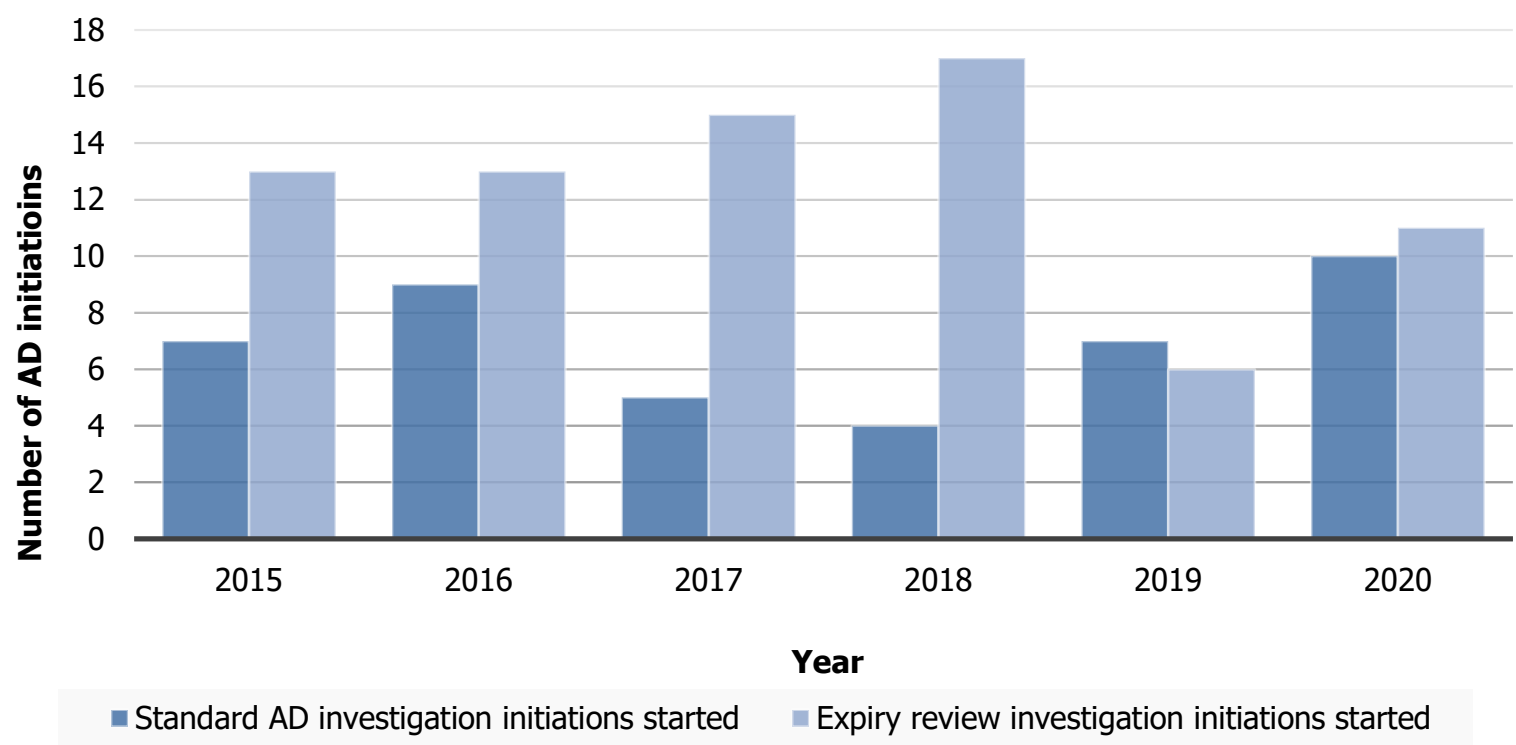

Source: Authors' own processing

Figure 2 illustrates the development of initiations of EU antidumping investigations during the observed period of years 2015-2020. In order to monitor the impact of the COVID-19 pandemics on EU AD investigations, it is important to observe this particular indicator considering the durations of the individual stages of the investigation. Considering the standard $A D$ investigation initiations, the trend of this type was fluctuating. The highest levels were achieved in 2016 and 2020, when at least 9 antidumping investigations started. On the other hand, the lowest level of investigation initiations occurred in 2018, when only 4 of them started. However, taking into account the expiry review investigation initiations, the highest level was achieved in 2018. After this year, there was a striking decrease in 2019, when only 6 of them started. In 2020, the Graph shows a renewed increase in value of this type of investigations. It is important to point out that during 2020, the COVID-19 pandemics began. Despite this fact, the increase in the number of investigations during 2020, compared with 2019, was not significant, as for example during 2018. It shows that the COVID-19 pandemic may not have substantial negative or positive impact on the number of antidumping investigations of EU. However, there is still a risk of existence of potential unfair practices made by the foreign businesses during the economic recession which will be the issue to solve in next periods. This is evidenced by the fact that as early as the beginning of 2021 , the European Union imposed a provisional anti-dumping duty as the preliminary result of initiation started during COVID-19 pandemics (May 2020) relating to imports of certain hot-rolled flat products of iron, non-alloy or other alloy steel originating in Turkey. (European Commission, 2021).

Concerning the commodity structure of potential dumping trade operations and expiry review process investigated by the European Commission, there is a variation of products involved. Based on the trade database of European Commission, the figure below illustrates the share of groups of such products on the whole number of products involved in the investigations initiated in 2020 together with the expiry review investigations initiated in 2020. 
Fig. 3 Commodity structure of $A D$ investigations and expiry review AD investigations in 2020

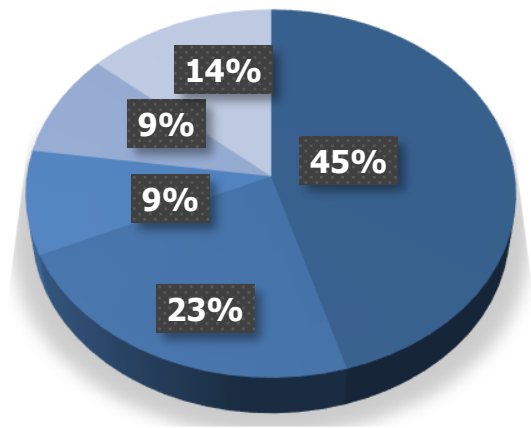

\author{
- Products made from iron and steel \\ - Products made from aluminium and silicium \\ - Chemical products \\ Glutamate and citric acid \\ Others
}

Source: authors' own processing based on European Commission, 2021

This figure shows that the commodity structure of $A D$ investigations and expiry review $A D$ investigations initiated in 2020 consists of most steel and iron products or components (45 $\%)$. Based on the general knowledge of international trade, these products are the most represented concerning the illegal trade operations. The group of products made from aluminium and silicium reached the level of $23 \%$ in $A D$ investigations and expiry review $A D$ investigations, while chemical products, glutamate and citric acid were involved in the investigation process by $9 \%$. The group "Others" (14\%) consists of products that are assorted, e. g. biodiesel, optical fibre cables etc. In comparison with previous year, according to the Commission's statistics, the commodity structure of AD investigations and expiry review $A D$ investigations has not changed significantly, as the dumping trade with such groups of products fluctuated from year to year relatively in the same way.

Taking into account the development of GDP, the statistics of percentage change in GDP of chosen countries that are involved the most in the process of EU AD investigations are shown in Figure 4 below. The data were researched quarterly, during the observed period of 6 years (2015-2020) while each indication is compared to the previous period.

Fig. 4 Percentage change in GDP quarterly compared to previous period (2015-2020)

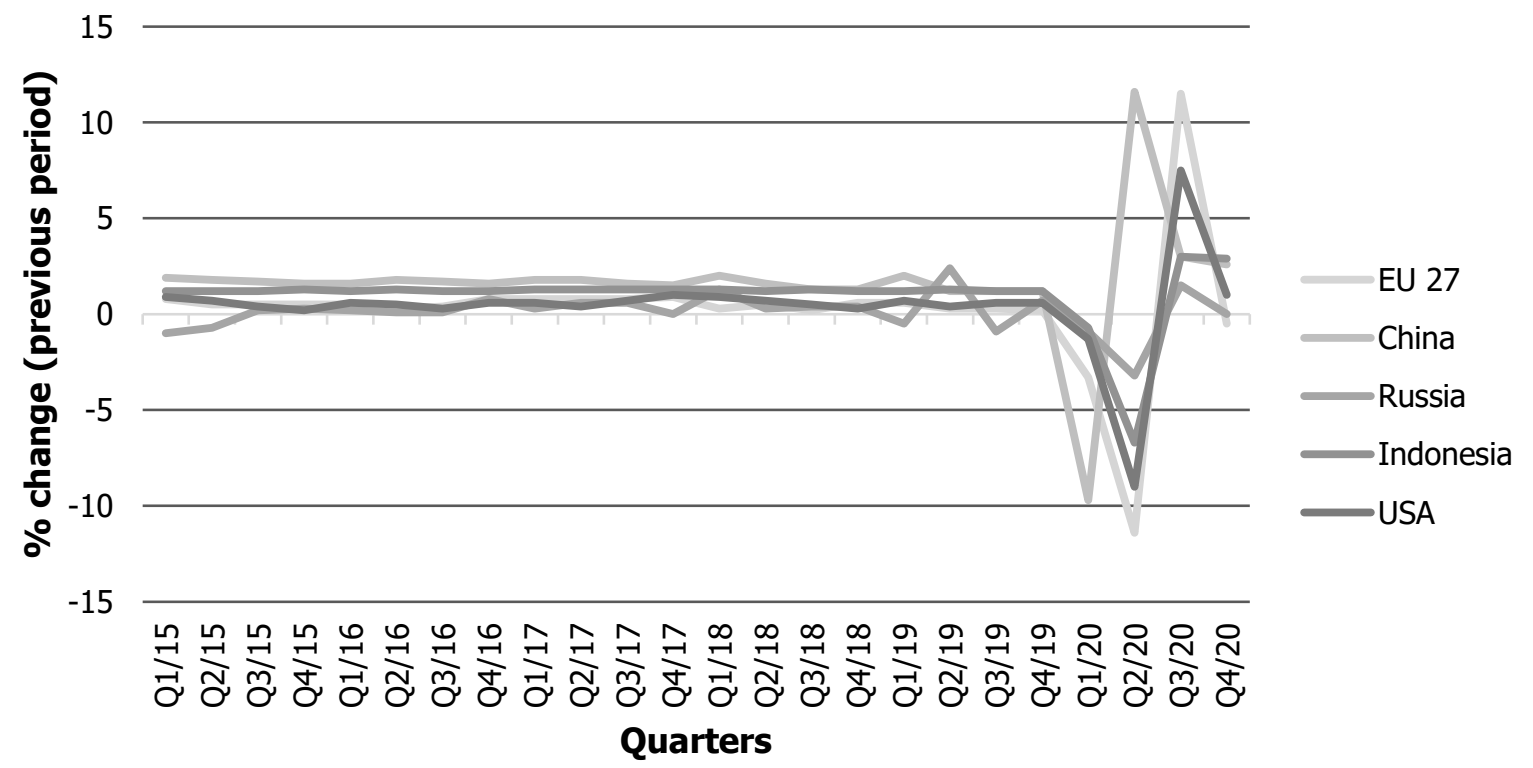

Source: authors' own processing based on OECD, 2021 
From the first quarter of 2015, there was not any significant percentual change in GDP till fourth quarter of year 2019. All researched subjects had relatively stable development of this change, except Russia which shows more fluctuating trend during the whole observed period. It is important to mention that the GDP of Russia was not significantly influenced by the COVID-19 pandemics, as there is only small decrease in GDP percentage change. While observing the GDP change in China, there is a deviation, when the significant percentual decrease occurred in first quarter of $2020(-9.7 \%)$ and at the end of the second quarter, there was a significant percentual increase in GDP (11.6\%). It was because China suffered from the COVID-19 pandemics earlier (as the country with the first case of disease) than the rest of the world. Indonesia had the most stable development of GDP from the first quarter of 2015 till 2020, when there is the decline in GDP due to the COVID-19 pandemics. The most significant percentual decrease in GDP compared to previous period had EU27 as a group. In the first quarter of 2020, there was $9.7 \%$ decrease in GDP, while in the second quarter the decrease in EU GDP reached 11.4\%. After the first "wave" of COVID-19 pandemics, there was an increase in all observed countries, but after the second "wave" occurred, naturally, it brought the significant decrease in fourth quarter of 2020 again, except Indonesia and China where the GDP increased by $2.9 \%$ compared to previous period, resp. $2.6 \%$. The specific situation occurred in USA, even the development of GDP was relatively stable till the first quarter of 2020 like in other countries, but after the GDP decrease by $9 \%$ in second quarter of 2020, the second highest increase from all observed countries occurred in third quarter of 2020 $(7.5 \%)$.

\section{CONCLUSION}

Concerning the review of the literature, it offers both the theoretical rationale for the impact of the economic recession on the increase of $A D$ investigations and several empirical studies are available to confirm or refute this relationship. Their results can be summarized in the sense of increasing the number of $A D$ investigations when deeper economic recession occurs. Taking into consideration the short term view, the short changes in the business activity of particular subjects have no significant impact on the number of $A D$ investigations initiated. According to the review, the GDP growth has negative impact on the number of $A D$ submissions. In other words, according to one of the study, the fall in domestic real GDP increased the number of submissions by more than $20 \%$.

The aim of this paper was to find out how the COVID-19 pandemic and the following economic recession has affected the antidumping investigations in the EU. Primarily, the COVID-19 pandemics affected the whole process of investigations in the sense that there is no possibility of carrying out a spot verification by the EU bodies, as it is usually done physically, and it is necessary to protect human health and eliminate the spread of the virus. The duration of $A D$ investigation is affected too. When the virus is mostly spread in particular country, the specific measures are implemented, including the lockdowns or closure of businesses, so the economic activity of the businesses from that country is suspended. Concerning this fact, the deadline for replying to the questionnaires could be extended by 7 days. If the situation regarding the pandemic is critical in the country, after providing all the evidence of the inability to cooperate with the EU, the deadline can be extended by another 7 days.

We have also compared whether there was an increase in the number of $A D$ investigations initiated including the expiry review investigations in 2020 compared to previous years. As researched, the number of investigations mentioned was not significantly increased even though there was a significant GDP growth decrease in the observed countries in the second quarter of 2020, when the pandemics was spread the most. In more detail, the GDP growth decline occurred in EU27 (-11.4\%), but also in the countries from which the products being imported came from, namely in China, where the GDP growth decline reached almost $-10 \%$. 
Oppositely, the lowest decline occurred in Russia (-3.2 \%). It is important to add, that China has suffered from the GDP decline during the first quarter of 2020, not the second, as the country was the first with beating the COVID-19 pandemics.

All things considered, the COVID-19 pandemics has not led to an increase in the number of proceedings yet, which is in line with Jallab's findings. So far, this is a short-term recession or decline in GDP (but very significant). In the event that the pandemics and the subsequent economic recession persist for a longer period of time, we assume that it will also be reflected in an increase in the number of AD proceedings. In any case, we recommend further research in this area, especially in the case of ongoing hosp. recession.

\section{ACKNOWLEDGEMENT}

This paper is part of the internal grant project PMVP No. I-21-110-00 of the University of Economics in Bratislava for young teachers, researchers and doctoral students entitled "The impact of geopolitical changes of the EUs foreign trade relations with selected countries in the $21^{\text {st }}$ century".

\section{REFERENCES}

Baláž, P. et al. (2019). Medzinárodné podnikanie. Bratislava: Sprint 2.

Barattieri et al. (2021). Protectionism and the business cycle. Journal of International Economics. 129. https://doi.org/10.1016/j.jinteco.2020.103417.

Bown, C. P., \& Crowley, M. A. (2013). Import protection, business cycles, and exchange rates: Evidence from the great recession. Journal of International Economics. 90(1), 50-64. https://doi.org/10.1016/j.jinteco.2012.12.001.

Curran, L. (2015). The impact of trade policy on global production networks: the solar panel case. Review of International Political Economy. 22(5), 1025-1054. https://doi.org/ 10.1080/09692290.2015.1014927.

European Commission. (2014). Investigations. Retrieved January 20, 2021, from https://trade.ec.europa.eu/doclib/docs/2013/april/tradoc_151022.pdf

European Commission (2015). Notices. Retrieved January 10, 2021, from https://trade.ec.europa.eu/tdi/notices.cfm?syear=2015

European Commission (2016). Notices. Retrieved January 10, 2021, from https://trade.ec.europa.eu/tdi/notices.cfm?syear=2016

European Commission (2017). Notices. Retrieved January 10, 2021, from https://trade.ec.europa.eu/tdi/notices.cfm?syear=2017

European Commission (2018). Notices. Retrieved January 10, 2021, from https://trade.ec.europa.eu/tdi/notices.cfm?syear=2018

European Commission (2019). Notices. Retrieved January 10, 2021, from https://trade.ec.europa.eu/tdi/notices.cfm?syear=2019

European Commission (2020). Notices. Retrieved January 10, 2021, from https://trade.ec.europa.eu/tdi/notices.cfm?syear $=2020$

European Commission. (2020). Announcement on the consequences of the COVID-19 outbreak on anti-dumping and anti-subsidy investigations. Procedures relating to the implementation of the common commercial policy. Retrieved January 20, 2021, from 
https://eur-lex.europa.eu/legal-

content/EN/TXT/PDF/?uri=CELEX:52020XC0316(02)\&from=EN

European Commission. (2021). COMMISSION IMPLEMENTING REGULATION (EU) 2021/9 of 6 January 2021 imposing a provisional anti-dumping duty on imports of certain hot-rolled flat products of iron, non- alloy or other alloy steel originating in Turkey. Retrieved January 20, 2021, from

https://eur-lex.europa.eu/legal-content/EN/TXT/PDF/?uri=CELEX:32021R0009\&from=EN

Feinberg, R. (1989). Exchange Rates and "Unfair Trade". The Review of Economics and Statistics. 71(4), 704-707. https://doi.org/10.2307/1928116

Feinberg, R. (2003). Exchange Rates and U.S. Dumping Petitions Revisited: Does Commerce Matter?'. Mimeo.

Felbermayr, G \& Sandkamp, A. (2020). The trade effects of anti-dumping duties: Firm-level evidence from China. European Economic Review. 122. https://doi.org/ 10.1016/j.euroecorev.2019.103367.

Jallab, Mustapha et al. (2007). Antidumping Procedures and Macroeconomic Factors: A Comparison between the United States and the European Union. Global Economy Journal. 6, 5-5. https://doi.org/10.2202/1524-5861.1173.

Park, S. (2009). The trade depressing and trade diversion effects of antidumping actions: The case of China. China Economic Review. 20(3). https://doi.org/10.1016/j.chieco.2009.03.006.

Sandkamp, A. (2020). The trade effects of antidumping duties: Evidence from the $2004 \mathrm{EU}$ $\begin{array}{lllll}\text { enlargement. Journal of International Economics. } & 123 .\end{array}$ https://doi.org/10.1016/j.jinteco.2020.103307.

Szatmári, Zs. (2020). Global Trade and Customs. A Practical Comparison of Major Jurisdictions. Amsterdam: IBFD. 